\title{
Yellow Fever Vaccine in Brazil: A Revolt Backwards 100 Years Later?
}

\author{
João Paulo Martins do Carmo* \\ UEG Campus Itumbiara-GO, Brazil
}

*Corresponding author: João Paulo Martins do Carmo, University of São Paulo, Universidade Estadual de Goiás, Campus Itumbiara-GO, Brazil

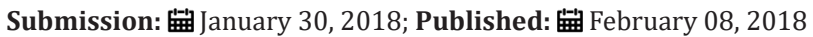

\section{Editorial}

Who arrives in Rio de Janeiro from the Galeão Airport heading to the famous Ipanema and Copacabana beaches (who haven't heard of the girl, from Tom Jobim's song, and the place immortalized in Barry Manilow's voice?) is able to see the Castelo Mourisco (which would be, in a free translation, something like "the Mourish Castle"), head of our Foundation Oswaldo Cruz - FIOCRUZ. In March 2017, the year Oswaldo Cruz-100 years of his legacy in Brazil was instituted to showcase his role in science and health in a national project. He was head of the group wishing to shape the small serotherapeutic lab, focused in vaccines and sera production, into a great experimental medicine one, like the Paris' Institute Pasteur, where he had studied Microbiology, Serotherapy and Immunology, and Legal Medicine at the Toxicology Institute. Heading the General Directory of Public Health, the young medical doctor and scientist also had to implement a sanitary campaign to fight smallpox and yellow fever, which together with plague formed the triple epidemics that devastated Rio de Janeiro in the first years of the XX century. The political situation allowed unpopular measures to be taken: it was a dictatorial regimen with authoritarian traits. The vaccination was mandatory: without a certification of immunization, it was hard to get a job or even to get married.

Following the Havanese theory by Carlos Finlay, approved by a North American commission, Oswaldo Cruz started the campaign to fight the mosquitos, based on the assumption that they were the yellow fever vectors, although there was no scientific evidence yet for which species or who would be its transmitter. The campaign consisted in eliminate any possible form of transmission in the population houses. In 1904 there was a popular riot, called the Vacine Revolt, against the mandatory vaccination against smallpox in Rio de Janeiro, the federal capital then. In 1907, he was recognized internationally and won a golden medal in the 14th International Congress of Hygiene and Demography of Berlin, in Germany. In 1908, he was received as a national hero, and in the next year, the Serotherapic Institute receive his name.The Rockefeller Pavilion is one of the facilities in the Institute of Technology in Immunobiologicals (Bio-Manguinhos/FIOCRUZ), where the lab to produce the yellow fever vaccine was built in the 40's decade. Since its creation in 1971, Bio-Manguinhos produces millions of vaccine doses annually, $14 \mathrm{mi}$ of doses in 2016. In October 2001, the unity obtained the certification of Good Manufacturing Procedures (GMP) of the yellow fever by WHO to act as its international provider.

Although the efforts of the Brazilian scientists and health providers and workers, unfortunately, however, there has been an outbreak of yellow fever in the last 3 years in Brazilian States where normally there are no epidemics, like Espírito Santo and Minas Gerais, and more recently, Rio de Janeiro and São Paulo. Recently, this outbreak has made the Brazilian people queue at health clinics where the vaccine is provided for free, reducing the stocks of vaccine available. Usually, the Amazon region is regarded as an endemic region because of the mosquito behavior. Until mid-1930s, it was believed that the disease was transmitted only by the Aedes aegypti [1] (which nowadays also transmits dengue, chikungunya and zika), which is related to the urban cycle, but we know now that it may be also transmitted by other species like Haemagogus and Sabethes, which are related to the wild cycle. Today, there is a revolt in the Brazilian health clinics because the population has understood the need to vaccinate against yellow fever, but there isn't enough vaccine for everyone in the non-endemic areas who wishes to get vaccinated. The solution found by the health managers was to fractionate the dosage used, so that everyone can be attended.

Studies performed in Congo and Mozambique, which are endemic áreas for yellow fever, have shown good and longterm results. Although the Brazilian population seems to be well education towards whom should be vaccinated, there is still a little bit of confusion about the monkeys being or not transmitter of the disease for humans. It is important to clarify that they are so victims are us, and they should not be killed, because they serve us as sentinels: if they die in the wild, that could be an indication, even though not a proof, that there may be infected monkeys with yellow fever. A question that pops up in our minds is: what has caused this increase? Studies had shown that there was an association between an accident in a Brazilian barrage, contaminating the water with heavy metals (and now it is not a metaphor for the hard rock songs), which destroyed the Rio Doce ("Sweet River", which 
became a bitter one), and all forms of life related to it: fishes, algae, fungi, bacteria, frogs and snakes, the last two of this list who are natural predators of mosquitoes. In this scenario, it is not hard to predict the near future: mosquitoes are able to proliferate without precedents, increasing the risk of acquiring any of the 4 kinds of viruses mentioned (yellow fever, zika, chikungunya or dengue). Add to this the rainy season, the warm weather and garbage accumulated over the years, and we have a recipe for mosquitoes to proliferate like crazy, as Fritj of Capra would reinforce with his holistic point of view ("mutation point", to be more exact). If they are infected, a brave new world of emergent and reemergent diseases are welcome (not much) [2-5].

So, this is a possibly never before imagined context of this wonderful transdisciplinary journal: everyone can realize works in areas with so rich, interdisciplinary as distant as microbiology, immunology, infectious diseases, parasitology, entomology, pathology, behavior, public health, ecology, evolution, genetics, molecular biology, environment, vaccines, and so on, brought closer all together, but not limited to these.

Thank you for your reading, Hope you enjoy this journey!

\section{References}

1. (2017) Aedes aegypti, Haemagogus and Sabethes: learn more about them. Researchers explain the role of each insect in the transmission of yellow fever (Researchers explain the role of each insect in yellow fever transmission). Revista de Manguinhos, FIOCRUZ. Portuguese.

2. (2017) Oswaldo Cruz: um legado centenário (a centennial legacy). Revista de Manguinhos, FIOCRUZ. Portuguese.

3. Sclyar M (2012) Oswaldo Cruz \& Carlos Chagas: O nascimento da ciência no Brazil (The science offspring in Brazil). Imortais da Ciência. Portuguese.

4. (2005) Vaccine, Sera and Immunizations (Vaccine, Sera and Immunization). In: Buss PM, Temporao JG, Carvalheiro JR (Eds.), Fiocruz, Brazil, Portuguese.

5. (1997) The Web of Life. CAPRA, F. Harper Collins Publishers, London.

\section{Your subsequent submission with Crimson Publishers} will attain the below benefits

- High-level peer review and editorial services

- Freely accessible online immediately upon publication

- Authors retain the copyright to their work

- Licensing it under a Creative Commons license

- Visibility through different online platforms

- Global attainment for your research

- Article availability in different formats (Pdf, E-pub, Full Text)

- Endless customer service

- Reasonable Membership services

- Reprints availability upon request

- One step article tracking system 